\title{
Consensus
}

Volume 29

Issue 2 Leavening the Lump

Article 21

$11-11-2004$

\section{Sensuous worship: Jesuits and the art of the early Catholic reformation in Germany}

Diane E. Peters

Follow this and additional works at: http://scholars.wlu.ca/consensus

\section{Recommended Citation}

Peters, Diane E. (2004) "Sensuous worship: Jesuits and the art of the early Catholic reformation in Germany," Consensus: Vol. 29 : Iss. 2 , Article 21.

Available at: http://scholars.wlu.ca/consensus/vol29/iss2/21

This Book Reviews is brought to you for free and open access by Scholars Commons @ Laurier. It has been accepted for inclusion in Consensus by an authorized editor of Scholars Commons @ Laurier. For more information, please contact scholarscommons@wlu.ca. 


\section{Sensuous Worship: Jesuits and the Art of the Early Catholic Reformation in Germany}

Jeffrey Chipps Smith

Princeton, New Jersey: Princeton University Press, 2002.

261 pages, $\$ 67.37$ Hardcover

Sensuous Worship provides the first detailed study of the Jesuits' revitalization of German Catholic religious art and culture in the aftermath of the Protestant Reformation. Between 1570 and 1648 they were responsible for the erection or renovation of over thirty major churches in Germany.

Smith's study interweaves Counter-Reformation theology and architectural history. He describes the spiritual crisis of Catholicism and the threat of its extinction in Germany in the mid-sixteenth century. The first Jesuit came to Germany in 1540, in the same year that the Society of Jesus was established. The order grew rapidly in both membership and influence. The major challenge which the Jesuits took upon themselves was "to re-establish or re-form Catholic identity through education" (3).

Since the time of Pope Gregory the Great in the sixth century, the Roman Catholic church had upheld the didactic value of art. For the Jesuits, visual art was bound to the idea of individual Christian formation and spiritual maturation.

Jesuit art owes its ideological foundation to St. Ignatius Loyola, the Society's founder. His Spiritual Exercises provided a framework for achieving salvation through self-knowledge and union with God. This process involved drawing upon the powers of all the senses to heighten one's mental image of the divine. An entire chapter of Smith's book is devoted to the examination of Ignatius' path to spiritual self-discipline and to the type of Jesuit pictorial theory which grew out of it.

The most interesting chapter, "St. Michael's and the Worshipper: Ways to Read a Church," focusses on St. Michael's Church in Munich, pointing out how the artistic program was designed to provide worshippers with a "progressive religious experience" (79). In descriptions of St. Michael's and other German Jesuit churches, the terms "drama", "theatricality" and "opulence" are used frequently. While these characteristics were condemned by Protestant Reformers, in Jesuit thought they served not only to attract the
Published by Scholars Commons @ Laurier, 2004 
faithful, but also to stimulate their spiritual imaginations and to provide them with a foretaste of the heavenly kingdom.

Although Smith's Sensuous Worship documents churches of a particular time and place, it raises issues which have continuing relevance for pastors, students, and general readers. The power of art to convey knowledge of God should not be underestimated, especially in a contemporary culture which places high value on the visual. What is seen in churches, especially by children and young people, may have as much or more impact than what is heard. Lessons can be learned from the Jesuit emphasis on training worshippers to recognize and to meditate on the spiritual significance of church art.

Sensuous Worship contains 188 illustrations, all reproduced in black and white. The pictures do little to convey the splendour of Baroque church architecture, although the absence of colour plates undoubtedly helped to lower production costs. The fact that many of the photographs came from pictorial archives also serves as a reminder of the costs of war on Germany's cultural and artistic heritage, since a number of the buildings discussed have not survived intact to the present day.

Jeffrey Chipps Smith holds the Kay Fortson Chair in European Art at the University of Texas, Austin. He is the editor of New Perspectives on the Art of Renaissance Nuremberg and the author of Nuremberg, A Renaissance City, 1500-1618 and German Sculpture of the Later Renaissance, c.1520-1580: Art in an Age of Uncertainty.

Diane E. Peters

Wilfrid Laurier University/Waterloo Lutheran Seminary

Waterloo, Ontario 